\title{
PENGEMBANGAN PERANGKAT BAHAN AJAR TEMATIK TEMA 8 SUBTEMA 1 MANUSIA DAN LINGKUNGAN BERBASIS KEARIFAN LOKAL SISWA KELAS V SEKOLAH DASAR
}

\author{
Netti Jumiati, Mohammad Siddik, Surya Sili \\ Universitas Mulawarman \\ nettijum@gmail.com
}

\begin{abstract}
Abstrak
Penelitian ini bertujuan mengembangkan perangkat bahan ajar tematik tema 8 subtema 1 manusia dan lingkungan berbasis kearifan lokal siswa kelas V sekolah dasar, melalui pendekatan saintifik. Penelitian ini merupakan Research and Development (R\&D) dengan model teori Dick \& Carey. Teknik analisis yang digunakan pada penelitian ini merupakan analisis deskriptif. Subyek penelitian pada siswa kelas V SDN 002 Karangan, analisis data dengan mengkonversi skor skala rating. Penelitian ini menghasilkan perangkat bahan ajar tematik berbasis kearifan lokal yang layak. Melalui penilaian aspek isi, aspek bahasa, aspek penyajian, strategi pembelajaran, dan aspek tampilan. Persentase penilaian oleh ke tiga ahli yaitu ahli pembelajaran $89 \%$, ahli media $81,07 \%$, dan ahli materi $84,78 \%$, dengan rerata perolehan $84,59 \%$. Produk memenuhi kriteria kepraktisan berdasarkan keterlaksanaan perangkat bahan ajar dengan perolehan nilai 85,4\% serta responden guru dan siswa yang termasuk dalam kategori sangat baik. Produk memenuhi kriteria keefektifan berdasarkan hasil belajar siswa pada uji kelas riil dengan nilai ketuntasan $88 \%$. Pengembangan perangkat bahan ajar tematik berbasis kearifan lokal ini mengacu pada silabus dan rencana pelaksanaan pembelajaran yang dikembangkan disesuaikan dengan kegiatan pembelajaran.
\end{abstract}

Kata Kunci: perangkat pembelajaran, kearifan lokal.

\section{Pendahuluan}

Sejak tahun pelajaran 2013 menteri pendidikan telah menetapkan dan memberlakukan Kurtilas, yang bertujuan agar siswa mampu memiliki bekal sikap, berkarakter, pengetahuan dan ketrampilan yang cukup untuk penyelesaian masalah dalam kehidupan. Model pembelajaran yang dikembangkan adalah pembelajaran tematik yang menggunakan pendekatan saintifik. Pendekatan saintifik adalah pembelajaran yang meliputi beberapa aktivitas ilmiah yaitu mengamati, menanya, menalar, mencoba, mengolah, menyajikan, menyimpulkan, mengkomunikasikan. Sisi positif sebuah pendekatan saintifik adalah dapat mendorong siswa untuk belajar lebih aktif dengan basis aktivitas.

Menteri Pendidikan dan Kebudayaan Muhammad Nuh mengatakan pemerintah menyiapkan kurikulum 2013 ini dalam satu paket bersama silabusnya. Kalimat satu paket dapat dianalogikan kebijakan kurikulum dan silabus yang dibuat pemerintah ini sebagai suatu produk yang berukuran sama baik di kota maupun di luar kota. Dalam lampiran IV Permendikbud Nomor 81A tahun 2013 ditegaskan bahwa pembelajaran di sekolah tingkat dasar dikembangkan secara tematik, keterpaduan lintas mata pelajaran untuk mengembangkan sikap, keterampilan, dan pengetahuan serta mengapresiasi keragaman budaya lokal. Salah satu kegiatan yang dapat dilakukan adalah dengan pengintegrasian kearifan lokal dalam pembelajaran (Khusna, Shufa, \& Artikel, 2018).

Sekolah Dasar Negeri 002 Karangan termasuk sekolah yang aktif dalam mengikuti pelatihan-pelatihan ataupun sosialisasi tentang Kurikulum 2013, namun pada kenyataannya dalam implementasinya di lapangan masih terdapat beberapa kendala.

Salah satu kendala yang sering dihadapi oleh guru melakukan kegiatan pembelajaran apa yang telah tertulis pada dari Kementrian Pendidikan dan Kebudayaan. Kegiatan pembelajaran yang dirancang tanpa melihat situasi, kondisi geografis, karakter siswa selama proses pembelajaran berlangsung. Sedangkan setiap daerah memiliki kebutuhan yang berbeda-beda dalam mempersiapkan pembelajaran di kelas. Kendala lain yang dihadapi adalah ketidaksesuaian antara rencana pelaksanaan pembelajaran (RPP) dan buku siswa (BS). Dalam arti masih ada terdapat kesalahan penulisan sehingga membuat guru dan siswa bingung.

Pengalaman peneliti selama mengajar di SDN 002 Karangan yang multikultur, pemaknaan terhadap pembelajaran berbasis kearifan lokal dalam dunia pendidikan belum 
dilaksanakan secara maksimal. Dapat dilihat dari kegiatan yang dilakukan warga sekolah selalu monoton pada sesuatu yang terbaru sesuai dengan modernisasi saat ini, dengan hasil yang kurang memuaskan.

Berdasarkan paparan dan kendala diatas, peneliti berinisiatif ingin mengembangkan perangkat bahan ajar pembelajaran sebagai buku pendamping bagi guru dan siswa. Mengingat kurangnya pemahaman siswa pada kearifan lokal dan unsur nilai-nilai budaya bangsa yang dengan perlahan dilupakan anak bangsa, yang disebabkan teknologi era digital. Perangkat yang dikembangkan adalah berupa bahan ajar/materi pembelajaran tematik berbasis kearifan lokal.

Kearifan lokal dalam dunia pendidikan adalah bagian dari upaya meningkatkan ketahanan nasional sebagai suatu bangsa yang multikultur, banyak keteladanan, kebijaksanaan hidup, budaya nusantara yang plural dan dinamis merupakan sumber kearifan lokal yang tidak akan mati, karena semuanya merupakan kenyataan hidup (living reality) yang tidak dapat dihindari.

Hubungan antara pendidikan dengan kearfian lokal dapat dijelaskan melalui pasal 2 UU RI Tahun 2003 tentang Sistem Pendidikan Nasional, yaitu "Pendidikan Nasional berlandaskan Pancasila dan Undang-Undang Negara Republik Indonesia Tahun 1945”. Dalam pengembangan ini, menuntut adanya suatu pembelajaran berbasis kearifan lokal untuk meningkatkan prilaku berkarakter dan kecerdasan intelektual peserta didik. Oleh sebab itu, pelaksanan pembelajaran harus ditunjang oleh sistem pendukung model pembelajaran yang digunakan, misalnya alat dan bahan yang berorientasi pada aktivitas lingkungan (Zubaedi, 2011:294).

Dari semua yang dipaparkan peneliti, maka dirumuskan masalah pada pengembangan ini adalah sebagai berikut:

1) Bagaimana proses pengembangan perangkat bahan ajar pembelajaran tematik manusia dan lingkungan berbasis kearifan lokal siswa kelas V Sekolah Dasar?

2) Bagaimana kelayakan perangkat bahan ajar pembelajaran tematik manusia dan lingkungan berbasis kearifan lokal siswa kelas V Sekolah Dasar?
Mengacu pada rumusan masalah diatas, tujuan yang dapat dicapai dalam pengembangan perangkat bahan ajar pembelajaran tematik manusia dan lingkungan berbasis kearifan lokal siswa kelas V Sekolah Dasar yang layak dan sesuai dengan kebutuhan siswa sehingga dapat memberikan pengalaman belajar yang valid, efektif, dan praktis serta menyenangkan bagi siswa. Tujuan khusus penelitian ini adalah:

1) Menghasilkan pengembangan perangkat bahan ajar pembelajaran tematik manusia dan lingkungan berbasis kearifan lokal siswa kelas V Sekolah Dasar.

2) Mengkaji kelayakan pengembangan perangkat bahan ajar pembelajaran tematik manusia dan lingkungan berbasis kearifan lokal siswa kelas V Sekolah Dasar.

Berdasarkan paparan di atas, judul penelitian yang dilakukan adalah Pengembangan Perangkat Bahan Ajar Pembelajaran Tematik Manusia dan Lingkungan Berbasis Kearifan Lokal Siswa Kelas V Sekolah Dasar. Pengembangan ini bermanfaat secara teoritis, hasil penelitian ini dapat dijadikan sebagai dasar untuk pengembangan perangkat bahan ajar pembelajaran tematik pengetahuan umum yang berbasis kearifan lokal. Manfaat pengembangan secara praktis dapat dipaparkan sebagai berikut:

a) Manfaat pengembangan secara praktis bagi sekolah, hasil penelitian pengembangan ini dapat memberikan sumbang pemikiran, referensi, sehingga bermanfaat untuk semua pihak.

b) Manfaat pengembangan secara praktis bagi guru, dapat menciptakan suasana belajar yang bermakna, efektif dan efesien. melalui pembelajaran tematik berbasis kearifan lokal.

c) Manfaat pengembangan secara praktis bagi siswa, dapat memahami materi pembelajaran dengan cermat akan kearifan lokal di tengahtengah modernisasi saat ini, bisa berargument, berinovasi, dan berkarya dengan potensi yang dimiliki.

d) Manfaat pengembangan secara praktis bagi penelitian, sebagai referensi dalam pengembangan materi pembelajaran berikutnya. 


\section{METODE PENGEMBANGAN}

Model Pengembangan

Model pengembangan pada penelitian ini berfokus pada research and development $(R \& D)$. Produk yang dikembangkan berupa Perangkat Pembelajaran Tematik Berbasis Kerifan Lokal Pada Subtema 1 Manusia dan Lingkungan di kelas V Sekolah Dasar, teori yang digunakan Dick, Carey, dan Carey. 10 prosedur model pengembangan Dick, Carey, dan Carey dalam pengembangan perangkat bahan ajar pembelajaran tematik manusia dan lingkungan berbasis kearifan lokal siswa kelas $\mathrm{V}$ sekolah dasar, komponen yang dimaksud ini, yaitu: 1) Menganalisis kebutuhan dan identifikasi tujuan umum pembelajaran, 2) Melaksanakan analisis pembelajaran, 3) Mengidentifikasi tingkah laku masukan dan karakteristik siswa, 4) Merumuskan tujuan kinerja, 5) Mengembangkan butir-butir tes acuan patokan, 6) Mengembangkan strategi pembelajaran, 7) Mengembangkan dan melakukan pengajaran, 8) Merancang dan melakukan tes formatif, 9) Merevisi bahan pembelajaran, 10) Merancang dan melaksanakan tes sumatif.

Waktu penelitian pengembangan dilaksanakan pada semester 2 tahun pelajaran 2018/2019, pada bulan awal Nopember, setelah melakukan seminar proposal tesis. Tempat penelitian dilakukan pada kelas V SDN 002 Karangan, Kecamatan Karangan Kabupaten Kutai Timur. Subjek uji coba dalam penelitian pengembangan ini, peneliti melakukan uji coba sebanyak tiga kali dan melibatkan berbagai pihak yang terkait dan berkoordinasi melalui konsultasi yang progresif.

Adapun pihak uji coba secara aktif terdiri dari beberapa ahli dan beberapa tahapan, yaitu : 1) Uji coba ahli materi, oleh Bapak Sugiri,M.Pd, 2) Uji coba ahli media, oleh Bapak Syafi'i,M.Pd, 3) Uji coba ahli pembelajaran, oleh Bapak rubito,M.Pd, 4) Uji praktisi oleh Lince Turu', S.Pd, 5) Uji coba kelompok kecil sebanyak 20 orang siswa pada kelas $\mathrm{Vb}, 6$ ) Uji coba lapangan kelompok riil sebanyak 25 orang siswa pada kelas Va SDN 002 Karangan Kecamatan Karangan, Kabupaten Kutai Timur tahun pelajaran 2018/2019.

Jenis data yang digunakan dalam pengembangan ini adalah bersifat kualitatif dan kuantitatif. Data kualitatif di dapat dari hasil observasi, wawancara, dan angket subjek uji coba dalam bentuk catatan secara kualitatif pada kolom komentar di lembar instrumen yang telah disediakan atau langsung ke naskah produk. Hal ini dilakukan untuk mengetahui kelayakan perangkat pembelajaran tematik berbasis kearifan lokal yang dikembangkan. Data kuantitatif diperoleh dari ahli tim validator melalui uji coba dalam bentuk skala penilaian terhadap produk.

\section{HASIL PENELITIAN DAN PEMBAHASAN}

Proses pengembangan bahan ajar ini mengacu pada Model Dick and Carey. Dalam pelaksanaannya peneliti membagi menjadi 4 tahapan berdasarkan komponennya, yaitu:

Tahap 1 Proses Pengembangan

1) Mengidentifikasi tujuan umum pembelajaran Tahapan ini Peneliti melakukan telaah materimateri apa saja yang sudah dipelajari siswa melalui pembelajaran terdahulu yang terkait materi yang dikembangkan. Identifikasi juga dilakukan dengan observasi dan wawancara terhadap guru kelas V SDN 002 Karangan. Dari hasil telaahan ini dapat disimpulkan bahwa siswa dan guru memerlukan bahan ajar yang sesuai kebutuhan siswa. Maka peneliti berinisiatif mengembangkan bahan ajar berbasis kearifan lokal ditengah-tengah kondisi siswa yang multikultur agar memperoleh pembelajaran bermakna dan berkarakter dengan menggunakan pendekatan saintifik.

2) Melaksanakan analisis pembelajaran

Analisis dilakukan dengan melihat peta konsep pada bahan ajar dan kompetensi yang telah dicapai siswa dengan melihat Kompetensi Dasar dan Kompetensi Inti pada kurikulum yang digunakan siswa kelas V SDN 002 Karangan.

3) Mengidentifikasi tingkah laku masukan dan karakteristik siswa

Pada tahap ini peneliti menganalisis materimateri yang akan bermanfaat bagi siswa untuk disesuaikan dengan analisis kebutuhan, kondisi yang riil di masyarakat untuk memperoleh pembelajaran yang bermakna dan lebih siap dengan keadaan di luar lingkungan sekolah 
4) Merumuskan tujuan kinerja

Berdasarkan analisis tujuan pembelajaran dan pernyataan tentang perilaku awal, mencatat pernyataan khusus tentang apa yang dapat dilakukan oleh siswa setelah mereka menerima pembelajaran. Pembelajaran dimaksudkan untuk mengidentifikasi keterampilan-keterampilan yang dipelajari, kondisi pencapaian unjuk kerja. Kriteria pencapaian unjuk kerja ini bertujuan untuk menguraikan tujuan umum menjadi tujuan yang lebih spesifik.

5) Mengembangkan butir-butir tes acuan patokan

Berdasarkan tujuan yang akan dicapai maka peneliti mengembangkan suatu instrumen penilaian untuk mengukur kevalidan berdasarkan hasil lembar penilaian RPP dan LKPD, kepraktisan berdasarkan hasil observasi proses pembelajaran, dan keefektifan berdasarkan keterlaksanaan dan angket respon siswa dan tes hasil belajar siswa

6) Mengembangkan strategi pembelajaran

Pada tahapan ini peneliti mendesain pembelajaran lebih dominan pada keaktifan siswa berupa diskusi, kerja kelompok dan observasi berdasarkan konsep materi yang sudah dirancang.

7) Mengembangkan dan melakukan pengajaran Bahan ajar yang dirancang mengacu pada kurikulum 2013, menggunakan pendekatan saintifik dan berbasis kearifan lokal.

Tahap 2 penulisan dan penyusunan bahan ajar Hal yang dilakukan pada tahap ini adalah: menentukan komponen bahan ajar, menyusun penilaian bahan ajar, penyusunan awal bahan ajar, dan produksi awal bahan ajar.

Tahap 3 Validasi, Evaluasi dan Revisi

8) Merancang dan melakukan tes formatif

Tahapan validasi dilaksanakan terhadap bahan ajar untuk menghasilkan kelayakan produk dengan melalui uji ahli pembelajaran, uji ahli media dan uji ahli materi. Proses evaluasi formatif dilaksanakan dalam tiga kali, yaitu:

a. Uji perorangan, produk. Uji coba ini dilakukan kepada 5 orang siswa kelas $\mathrm{Vb}$ pada tanggal 25 Februari 2019 untuk memperoleh masukan awal tentang, berikut hasil uji perseorangan dapat dilihat pada tabel berikut:

Tabel 4.18 Tabel instrumen revisi uji perseorangan

\begin{tabular}{|c|c|c|c|c|c|}
\hline \multirow[t]{2}{*}{ No } & \multirow[t]{2}{*}{ Aspek penilaian } & \multicolumn{4}{|c|}{$\begin{array}{l}\text { Skor } \\
\text { penilaian }\end{array}$} \\
\hline & & 1 & 2 & 3 & 4 \\
\hline 1 & Kesalahan ketik & & $\sqrt{ }$ & & \\
\hline 2 & $\begin{array}{l}\text { Kesalahan } \\
\text { penggunaan tanda } \\
\text { baca }\end{array}$ & & $\sqrt{ }$ & & \\
\hline 3 & $\begin{array}{l}\text { Kata yang } \\
\text { seharusnya } \\
\text { menggunakan } \\
\text { huruf kapital }\end{array}$ & & $\sqrt{ }$ & & \\
\hline 4 & $\begin{array}{l}\text { Kata yang } \\
\text { seharusnya } \\
\text { menggunakan } \\
\text { huruf kecil }\end{array}$ & & $\sqrt{ }$ & & \\
\hline 5 & $\begin{array}{l}\text { Hal-hal lain yang } \\
\text { perlu diperbaiki }\end{array}$ & $\sqrt{1}$ & & & \\
\hline & Jumlah & 1 & 8 & & \\
\hline
\end{tabular}

b. Uji coba kelompok kecil yang terdiri 20 orang siswa pada kelas $\mathrm{Vb}$. Hasil respon siswa kelas kecil pada bahan ajar diperoleh nilai pada aspek materi adalah $76 \%$ termasuk dalam kategori baik, aspek bahasa diperoleh nilai $78,3 \%$ termasuk dalam kategori sangat baik, dan aspek ketertarikan diperoleh 75\% termasuk dalam kategori baik Kemudian hasil uji coba dikumpulkan sebagai bahan untuk revisi selanjutnya sesuai saran dan masukan dari validator dan angket siswa;

c. Uji coba lapangan yang melibatkan seluruh subjek dalam kelas yaitu 25 siswa pada kelas Va dengan menggunakan produk yang dikembangkan (kelas yang mendapatkan perlakuan). Hasil respon siswa kelas kecil pada bahan ajar diperoleh nilai pada aspek materi adalah $81 \%$ termasuk dalam kategori sangat baik, aspek bahasa diperoleh nilai $80 \%$ termasuk dalam kategori sangat baik, dan aspek ketertarikan diperoleh 81,6\% termasuk dalam kategori sangat baik.

Revisi dilakukan untuk menyempurnakan bahan pembelajaran sehingga lebih efektif bila digunakan dalam pembelajaran, memudahkan 
untuk mencapai tujuan pembelajaran yang telah ditetapkan.

Validasi, dimaksudkan untuk menilai kelayakan media yang dikembangkan sebelum diuji coba lapangan. Ahli materi pembelajaran memberi penilaian terkait dengan materi yang dikemas dalam bahan ajar, sedangkan ahli media/desain memberi penilaian terkait cara mengemas materi ke dalam media dan tampilan media. Validasi ini menggunakan pedoman penyekoran skala rating.

Tabel 4.28 Rekapitulasi Hasil Penilaian

Kevalidan Perangkat Pembelajaran

\begin{tabular}{|c|c|c|c|c|}
\hline \multirow[b]{2}{*}{$\begin{array}{l}\mathrm{N} \\
\mathrm{o}\end{array}$} & \multirow[b]{2}{*}{$\begin{array}{l}\text { Aspek Yang } \\
\text { Dinilai }\end{array}$} & \multicolumn{3}{|c|}{ Validator } \\
\hline & & $\begin{array}{l}\text { Ahli } \\
\text { Pembe } \\
\text { lajaran }\end{array}$ & $\begin{array}{l}\text { Ahli } \\
\text { Me } \\
\text { dia }\end{array}$ & $\begin{array}{l}\text { Ahli } \\
\text { Materi }\end{array}$ \\
\hline 1 & Aspek Isi & $85 \%$ & $95,8 \%$ & $79,1 \%$ \\
\hline 2 & Aspek Bahasa & $87,5 \%$ & $78,5 \%$ & $91,6 \%$ \\
\hline 3 & Aspek Penyajian & $87,5 \%$ & $75 \%$ & $80,7 \%$ \\
\hline 4 & $\begin{array}{l}\text { Aspek Strategi } \\
\text { Pembelajaran }\end{array}$ & $95 \%$ & & $85 \%$ \\
\hline 5 & Aspek Tampilan & $90 \%$ & $75 \%$ & $87,5 \%$ \\
\hline & Rata-rata & $89 \%$ & $\begin{array}{c}81,07 \\
\% \\
\end{array}$ & $84,78 \%$ \\
\hline & Kriteria & layak & layak & layak \\
\hline
\end{tabular}

9) Merevisi bahan pembelajaran

Revisi Produk, dilakukan untuk menyempurnakan perangkat bahan ajar pembelajaran tematik berbasis kearifan lokal yang dihasilkan berdasarkan hasil uji coba yang terdiri dari kelas kecil dan kelas riil. Pada tahap ini dilakukan evaluasi hasil penilaian dari para penilai yang dianalisis, dengan hasil revisi sebagai berikut:

A. Revisi ahli pembelajaran

Tabel 4.10 hasil revisi silabus

\begin{tabular}{|c|c|c|c|}
\hline No & $\begin{array}{c}\text { Yang } \\
\text { direvisi }\end{array}$ & $\begin{array}{c}\text { Sebelum } \\
\text { revisi }\end{array}$ & $\begin{array}{c}\text { Sesudah } \\
\text { revisi }\end{array}$ \\
\hline 1. & $\begin{array}{c}\text { Kata } \\
\text { tahu }\end{array}$ & tau & tahu \\
\hline
\end{tabular}

Tabel 4.12 Hasil revisi rencana pelaksanaan pembelajaran (RPP).

\begin{tabular}{|l|c|c|c|}
\hline No & $\begin{array}{c}\text { Yang } \\
\text { direvisi }\end{array}$ & $\begin{array}{c}\text { Sebelum } \\
\text { revisi }\end{array}$ & $\begin{array}{c}\text { Sesudah } \\
\text { revisi }\end{array}$ \\
\hline 1. & $\begin{array}{c}\text { Botol } \\
\text { aqua } \\
\text { bekas }\end{array}$ & aqua & $\begin{array}{c}\text { Air } \\
\text { mineral }\end{array}$ \\
\hline
\end{tabular}

Tabel 4.14 Hasil revisi Penilaian
Ahli Pembelajaran

\begin{tabular}{|l|l|l|l|}
\hline No & $\begin{array}{l}\text { Yang } \\
\text { direvisi }\end{array}$ & $\begin{array}{l}\text { Sebelum } \\
\text { revisi }\end{array}$ & $\begin{array}{l}\text { Setelah } \\
\text { revisi }\end{array}$ \\
\hline 1. & $\begin{array}{l}\text { Dari } \\
\text { aspek } \\
\text { tampilan } \\
\text { gambar }\end{array}$ & $\begin{array}{l}\text { Gambar } \\
\text { pada } \\
\text { materi } \\
\text { pembelaja } \\
\text { ran tidak } \\
\text { proporsio } \\
\text { nal sesuai } \\
\text { standar. }\end{array}$ & $\begin{array}{l}\text { Tampilan } \\
\text { gambar } \\
\text { pada } \\
\text { materi } \\
\text { pembelaja } \\
\text { ran } \\
\text { proporsio } \\
\text { nal sesuai } \\
\text { standar }\end{array}$ \\
\hline
\end{tabular}

B. Revisi ahli media

Tabel 4.16 Hasil Revisi Ahli Media Pembelajaran

\begin{tabular}{|c|c|c|}
\hline No & $\begin{array}{c}\text { Yang } \\
\text { direvisi }\end{array}$ & Revisi \\
\hline 1. & $\begin{array}{l}\text { Dari } \\
\text { segi } \\
\text { tampilan } \\
\text { cover } \\
\text { dan isi }\end{array}$ & $\begin{array}{l}\text { a) Cover sebaiknya } \\
\text { lebih spesifik } \\
\text { sesuai tema } \\
\text { pembelajaran } \\
\text { b) Untuk tampilan } \\
\text { bagian isi buku } \\
\text { harus ada } \\
\text { perbedaan dari } \\
\text { sebelum } \\
\text { dikembangkan dan } \\
\text { sesudah } \\
\text { dikembangkan. } \\
\text { c) Dalam } \\
\text { pengembangan } \\
\text { perangkat } \\
\text { hendaknya } \\
\text { perhatikan alokasi } \\
\text { waktu. }\end{array}$ \\
\hline
\end{tabular}

C.Revisi ahli materi

Tabel 4.18 Hasil revisi Penilaian Ahli Materi Pembelajaran

\begin{tabular}{|c|c|c|c|}
\hline No & $\begin{array}{l}\text { Yang } \\
\text { direvisi }\end{array}$ & $\begin{array}{l}\text { Sebelum } \\
\text { revisi }\end{array}$ & $\begin{array}{l}\text { Saran } \\
\text { revisi }\end{array}$ \\
\hline 1. & $\begin{array}{l}\text { Dari } \\
\text { aspek } \\
\text { penggu } \\
\text { nan } \\
\text { kata } \\
\text { dan }\end{array}$ & $\begin{array}{l}\text { Terdapat } \\
\text { pengguna } \\
\text { an kalimat } \\
\text { taksa, } \\
\text { penyempu } \\
\text { rnaan } \\
\text { pada }\end{array}$ & $\begin{array}{l}\text { Hindari } \\
\text { pengguna } \\
\text { an kalimat } \\
\text { taksa, } \\
\text { penyempu } \\
\text { rnaan } \\
\text { pada }\end{array}$ \\
\hline
\end{tabular}




\begin{tabular}{|c|c|c|}
\hline kalimat & $\begin{array}{l}\text { pengguna } \\
\text { an kata, } \\
\text { penulisan } \\
\text { pada } \\
\text { daftar } \\
\text { pustaka } \\
\text { belum } \\
\text { sesuai } \\
\text { alfabet, } \\
\text { tidak } \\
\text { mencantu } \\
\text { mkan } \\
\text { bahan dari } \\
\text { internet. }\end{array}$ & $\begin{array}{l}\text { pengguna } \\
\text { an kata, } \\
\text { penulisan } \\
\text { pada } \\
\text { daftar } \\
\text { pustaka } \\
\text { harus } \\
\text { sesuai } \\
\text { alfabet, } \\
\text { pencatuta } \\
\text { n bahan } \\
\text { dari } \\
\text { internet } \\
\text { harus } \\
\text { menamba } \\
\text { hkan kata }\end{array}$ \\
\hline
\end{tabular}

D. Revisi uji praktisi

Tabel 4.20 Hasil Revisi Uji Coba Praktisi

\begin{tabular}{|l|l|lr|}
\hline No & $\begin{array}{l}\text { Yang } \\
\text { direvisi }\end{array}$ & \multicolumn{1}{|c|}{ Revisi } \\
\hline 1. & $\begin{array}{l}\text { Dari segi } \\
\text { tampilan } \\
\text { isi }\end{array}$ & $\begin{array}{l}\text { Sebaiknya untuk skor } \\
\text { penilaian soal di } \\
\text { tampilkan }\end{array}$ \\
\hline
\end{tabular}

Dalam penelitian ini pengembangan hanya sampai pada tahap ke-9 yaitu evaluasi formatif dan merevisi produk, sedangkan untuk tahap ke-10 yaitu melaksanakan evaluasi sumatif tidak dilakukan sebagai masukan atau input perbaikan produk awal. Dengan alasan langkah pengembangan ini bertujuan untuk uji coba produk bahan ajar.

\section{Tahap 4 Produk akhir.}

Menghasilkan produk akhir berupa bahan ajar dengan menggunakan teori Dick and Carey.

Bahan ajar dikatakan layak apabila valid,praktis dan efektif.

Valid

Data yang diperoleh dari penelitian ini berupa data kuantitatif dan kualitatif berupa validasi ahli mengenai kelayakan instrumen, data validasi dan komentar ahli mengenai validitas perangkat pembelajaran yang dikembangkan.

\section{Kepraktisan}

Perangkat pembelajaran dikatakan praktis jika berada pada kriteria baik. Kriteria kepraktisan perangkat pembelajaran yang didasarkan lembar observasi keterlaksanaa perangkat pembelajaran, data angket respon siswa dan respon guru.

\section{Keefektifan.}

Perangkat bahan ajar dikatakan efektif apabila menunjukkan ketercapaian tujuan pembelajaran sesuai dengan indikator yang telah dijabarkan. Dari nilai tes hasil belajar siswa diatas KKM 75. Berdasarkan analisis data tes hasil belajar siswa uji lapangan dari segi ketuntasan terdapat 22 siswa dari 25 orang siswa memperoleh nilai skor $88 \%$, tes hasil belajar siswa sesuai yang diharapkan dengan kriteria sangat baik.

\section{KESIMPULAN}

Berdasarkan hasil deskripsi proses dan uji kelayakan pengembangan perangkat bahan ajar dengan subyek penelitian siswa kelas $\mathrm{Va}$ dan kelas Vb SDN 002 Karangan, dapat disimpulkan bahwa:

1. Proses pengembangan bahan ajar ini mengacu pada Model Dick and Carey, kemudian diadaptasi menjadi empat tahap, yaitu: 1) Tahap Proses Pengembangan, 2) Tahap Desain Produk, 3) Tahap Validasi, Evaluasi, dan revisi, 4) Tahap Produk Akhir. Dalam pembelajaran pada bahan ajar menggunakan pendekatan saintifik. Pada proses pengembangan bahan ajar mengalami tiga kali revisi baik dari judul cover, maupun materi bahan ajar. Dengan tiga ahli validasi yaitu validasi ahli pembelajaran, validasi ahli materi, dan ahli validasi materi serta uji praktisi (guru). Validasi dilakukan untuk mengetahui kelayakan bahan ajar. Pengembangan ini menghasilkan suatu perangkat pembelajaran berupa bahan ajar tematik berbasis kearifan lokal. Produk bahan ajar ini di uji coba pada siswa kelas V SDN 002 Karangan dengan respon cukup baik. Produk bahan ajar ini cukup membantu siswa baik dalam hal pengetahuan umum maupun tentang budaya di tengah-tengah modernisasi saat ini.

2. Perangkat bahan ajar layak digunakan berdasarkan aspek kevalidan, kepraktisan, dan keefektifan. Kevalidan bahan ajar dapat dilihat dari penilaian ahli pembelajaran dengan nilai $89 \%$; b) ahli media dengan nilai $81,07 \%$; c) ahli materi dengan nilai $84,78 \%$. 
Kepraktisan bahan ajar diperoleh dari keterlaksanaan perangkat pembelajaran, hasil aktivitas belajar, responden guru dan siswa.

Berdasarkan kesimpulan yang disampaikan maka dapat disampaikan beberapa saran sebagai berikut:

1) Perangkat pembelajaran yang dihasilkan dalam penelitian ini, dapat digunakan sebagai alternatif pendamping perangkat pembelajaran tematik dengan tema lingkungan sahabat kita karena sudah dinilai oleh tim validasi, uji praktisi dengan hasil sangat baik. Peneliti pengembangan perangkat bahan ajar pembelajaran tematik manusia dan lingkungan berbasis kearifan lokal siswa kelas V sekolah dasar ini, dapat dikembangkan lagi dengan menggunakan model atau metode yang berbeda.

2) Bagi para praktisi pendidikan, dalam menghadapi tantangan yang sangat kompleks di dunia pendidikan saat ini, mari kita berkarya, berbuat, menyajikan yang terbaik dan berinovasi. Untuk mempersiapkan generasi cerdas, berkarakter, berbudi pekerti luhur dan bermartabat. Kembangkan teoriteori ahli pakar pendidikan dengan membuat dan mengembangkan perangkat pembelajaran dengan ilmu pengetahuan dan teknologi, dengan tidak mengenyampingkan kearifan lokal, nilai-nilai unsur budaya bangsa kita yang majemuk.

\section{DAFTAR PUSTAKA}

Akhir, M. 2017.(tesis) Pengembangan Materi Ajar Bahasa Indonesia the Development of Indonesian Teaching Materials Based Character. Program Pascasarjana Universitas Negeri Makassar, 2017.

Ahmad., H. (2010).Kearifan Lokal sebagai Landasan Pembangunan Bangsa.Harmoni Jurnal Multikultural \& Multireligius.34(IX). Hlm. 5-8

Arikunto (dalam Irwan \& Nasution, 2016). Strategi Pembelajaran Efektif Berbasis Mobile Learning Pada Sekolah Dasar. (Jurnal Iqra). Diakses tanggal 01/09/2018

Asnaini, Adlim, Mahidin. (2016).Pengembangan lkpd berbasis pendekatan Scientific Untuk meningkatkan hasil belajar dan aktivitas Peserta didik pada materi larutan penyangga.
Program Pascasarjana Universitas Syiah Kuala Banda Aceh 23111, 193.

Astrini, L. Pengembangan Bahan Ajar Menulis Petunjuk, 448-462. Oleh, S. P., Prodi, N. N. I. M., Bahasa, P., \& Indonesia, S. (2013).

Aji, W. N. (2013). Model Pembelajaran Dick and Carrey Dalam. Model Pembelajaran Dick and Carrey Dalam Pembelajaran Bahasa Dan Sastra Indonesia, 1, 119-126. https://doi.org/10.23917/kls.v1i2.3631Dasar, D. I. S. (n.d.). No Title, 1-10.

Chen, Y. T., dan Li, Y. T. 2011. Development and evaluation of multimedia reciprocal representation instructional materials. International Journal of the Physical Sciences. 6(6): 1431-1439.

Chonga, V, D., Sallimah, dan Aicheongc, P, I. 2013. Using an Activity Worksheet to Remediate Students' Alternative Conceptions of Metallic Bonding. American International International Journal of Contemporary Research. 3(11):39-52.

Danim, Sudarwan, Media Komunikasi Bumi Aksara, Jakarta, 1995. Diakses tanggal 06/08/2018.

Departemen Pendidikan Nasional. (2008) Panduan Pengembangan Bahan Ajar.

Jakarta: Depdiknas. Diakses tanggal 23/08/2019.

Departemen Pendidikan Nasional. (2013) Draf Kurikulum 2013 untuk Sekolah Dasar SD/MI. Jakarta: Balitbang

Dick, M., \& Icare, D. A. N. M. (2014). Model dick and carey, dan model icare, (Mkdk 124).

Hernawan, $A$. 1991. (jurnal artikel) Pengembangan model pembelajaran tematik di kelas awal sekolah dasar. Diakses tanggal 22/04/2018.

Irianto, Agus Maladi. (2009). "Media dan Multikulturalisme" dalam Multikulturalisme Yogyakarta dan Identitas Keindonesiaan, (Editor: Sri Rahayu Budiarti dan Muslimin A.R. Effendy). Jakarta: Departemen Kebudayaan dan Pariwisata Republik Indonesia.Hal. 31-64.

Khusna Faela Shufa 1 Universitas Muria Kudus1 e-mail:_faela.rifa@yahoo.co.id. Pembelajaran Berbasis Kearifan Lokal Di Sekolah Dasar: Sebuah Kerangka 
Konseptual, 2018.

Lestariningsih. (2014). Evaluasi Hasil Belajar Siswa Yang Diberi Umpan Balik Positif Dan Negatif Pada Pokok Bahasan Pecahan. (Evaluation Of Student Learning To Be Positive And Negative Feed Back On The Subject Review Fractions), 2(1),65-74.

Maharani, M., Wati, M., \& Hartini, S. (2017). Pengembangan Alat Peraga Pada Materi Usaha Dan Energi Untuk Melatihkan Keterampilan Proses Sains Melalui Model Inquiry Discovery Learning ( Idl) Terbimbing. Berkala Ilmiah Pendidikan Fisika, 5(3), 351-367.

Mahnun, 2012. (jurnal) Media Pembelajaran (Kajian terhadap Langkah-langkah Pemilihan Media dan Implementasinya dalam Pembelajaran). Fakultas Tarbiyah Dan Keguruan Uin Suska Riau.

Mahgiyanto, I. (2016). Pengembangan Perangkat Pembelajaran Tematik Dengan Pendekatan Kontekstual ( Contextual Teaching And Learning ) Kelas Iii Di Sekolah Dasar Tahun Ajaran 2015 / 2016.

Mahirah, B. (2016). Evaluasi Belajar Peserta Didik (Siswa), I(36), 90-99.

Majid, A Perencanaan Pembelajaran, (Bandung: Remaja Rosdakarya, 2005), h. 24. Diakses tanggal 06/08/2018.

Masdiana, Budiarsa, I. M., \& Lamba, H. A. (2013). Penerapan Pembelajaran Tematik Untuk Meningkatkan Hasil Belajar Ipa Materi Pada Lingkungan Siswa Kelas I Sdn 018 Letawa Kecamatan Sarjo Kabupaten Mamuju Utara. Jurnal Kreatif Tadulako, 3(2), 190204.

Misriani, Cerita Rakyat Kalimantan Timur, Kantor Bahasa Provinsi Kalimantan Timur Badan Pengembangan Dan Pembinaan Bahasa Kementerian PendidikanDan Ebudayaan, Edisi pertama 2013. Diakses tanggal 18/09/2019.

Naway, F. A. (N.D.). Strategi Pengelolaan Pembelajaran.

Pembelajaran, P. P., Materi, P., Redoks, K., Pilar, E., Melalui, P., \& Study, L. (2012). Empat Pilar Pendidikan Melalui Lesson Study.

Nurfitriani, W \& dkk 2018, Thematic Text Book Development Based on LocalWisdom, 'Geography Education-Universitas Negeri
Malang Perum. Dian Anyar Blok N4 No 2A, Ciseureuh, Purwakarta-41118, Indonesia. Email: kaher.zain@yahoo.co.id*

Diakses tanggal 18/09/2019.

Octavia1, S. (2016). Pengembangan Buku Teks Kelas V Sekolah Dasar Berbasis Tematik Dengan Model Multiple Games. Vol 2, No 2, $\mathrm{Mei}$ 2016 http://journal.unesa.ac.id/index.php/PD.

Pendidikan Dasar, Pascasarjana Universitas Negeri Surabaya.

Panen (Dalam Sadjiati, 2012), (Modul) Hakikat Bahan Ajar (Drh. Ida Malati Sadjati, M. Ed).

Patimah Tanjung, Journal of Education 2018. Judul The Development Of Local Wisdom Of Labuhanbatu Based On Teaching Material Of Descriptive Text For 7th Grade Student At Smp Negeri 1 Bilah Barat, Indonesia

Permendikbud No. 65 Tahun 2013 tentang Standar Proses Pendidikan Dasar dan Menengah

Permendikbud Nomor 81a Tahun 2013, Tentang Implementasi Kurikulum. Jakarta.

Rahmadi, 2015 (Jurnal), Pengembangan Perangkat Pembelajaran Berbasis Pemecahan Masalah Berorientasi Pada Kemampuan Penalaran Dan Komunikasi Matematika, Available Online At: Http://Journal.Uny.Ac.Id/Index.Php/Pythago ras. Diakses Tanggal 05/112018.

Roikhwanphut.(2012). Knowledge and Local Wisdom: Community Treasure.International Journal of Humanities and Social Science.13(II). Hlm. 174-181.

Sibarani $R$, 2013. Pembentukan karakter berbasis kearifan lokal.online dalam http: WWW.Mesium. Pusaka-nias.org/2013/02/ kearifan lokal.html. Diadaptasi tanggal 09/02/2019.

Sadjati, I. M. (2012). Hakikat Bahan Ajar. Modul Pengembangan Bahan Ajar, 1-62. Retrieved From

Http://Repository.Ut.Ac.Id/4157/1/Idik4009M1.Pdf.

Suhadi, ( Dalam Santi \& Santosa, 2012) Pengembangan Perangkat Pembelajaran Menggunakan Pendekatan Saintifik Pada Materi Pokok Geometri Ruang Smp (Tesis), 2016. 
Suprijono, A. Cooperative Learning, Yogyakarta: Pustaka Belajar, 2014, hlm. 88. Diakses tanggal 06/08/2018.

Sutriyati, 2016. (Tesis) Pegembangan Bahan Ajar Meulis Essay Dengan Memanfaatkan Kearifan Lokal Melalui Pembelajaran Berbasis Proyek (Pbp) Siswa Sma. Diadaptasi 03/03/2019.

Wahab, Aziz, Abdul, 2012, Pengelolaan Pendidikan Berbasis Kearifan Lokal, Makassar. Program Pasca Sarjana Universitas Negeri Makassar.

Wahyudi, A 2014. Implementasi Sekolah Berbasis Kearifan Lokaldi SD Negeri Sendangsari Pajangan, Fakultas Ilmu Pendidikan Universitas Negeri Yogyakarta,2014.

Wulan, A.R(2001), Pengertian Dan Esensi Konsep Evaluasi, Asesmen, Tes, Dan Pengukuran. Fpmipa. Universitas Pendidikan Indonesia,1-2. Diakses Tanggal 27/09/2018.

Tan, C. (2005). Analysis Of Three Instructional Design Models. De-Research, 1-18. Diakses Tanggal 14/10/201
Undang- Undang Ri Tahun 2003. Pasal 2 Tentang Sistem Pendidikan Nasional. Di akses tanggal 22/08/208.

Unib, 2017 Perencanaan Pembelajaran Kurikulum 2013 Pendidikan Anak Usia Dini (Penelitian Deskriptif Kuantitatif Di Paud It Auladuna Kota Bengkulu)Annisa Eka Fitri Universitas Bengkulu

Email:Annisa300395@Gmail.Com_Sri Saparahayuningsih Universitas Bengkulu Email: Srisaparahayu@Yahoo.Co.Id Nesna Agustriana Universitas Bengkulu Email: Nesna_Ais@Yahoo.Co.Id. Di akases tangal 27/09/2018.

Valentina, A Y U, Riswandi, Rohani, C. (2014). Pengembangan Bahan Ajar Di Kelas V Negeri 2 Labuhan Ratu. Jurnal Skripsi, 2015. Retrieved From Njjuiiop. Diakses tanggal 08/08/2018

Zubaedi, 2011. Desain Pendidikan Karakter Konsepsi Danaplikasinya Dalam Lembaga Pendidikan. Jakarta,Kencana Prananda Media Group. Diadaptasi 02/09/2019 